\title{
Controle de oxidação no cultivo in vitro de embriões de estrelícia (Strelitzia reginae $)^{(1,2)}$
}

\author{
PATRÍCIA DUARTE DE OLIVEIRA PAIVA ${ }^{(3)}$, RENATO PAIVA ${ }^{(4)}$, MOACIR PASQUAL $^{(4)}$
}

\begin{abstract}
RESUMO
A propagação de estrelícia (Strelitzia reginae Ait.) é comumente realizada a partir da divisão de touceiras ou por sementes. As sementes possuem germinação lenta, além de dormência. O desenvolvimento desta planta é lento e, conseqüentemente, a produção de novas mudas também é demorada. Em conseqüência, a produção de mudas produzidas por planta matriz é baixa, indicando-se o cultivo in vitro para reprodução dessa espécie com eficiência. No entanto, durante o cultivo in vitro de estrelícia tem sido observada oxidação nos explantes e no meio de cultura, ocasionando danos nos mesmos. Objetivou-se então testar o efeito de antioxidantes suplementados ao meio de cultura. Utilizaramse carvão ativado, $\mathrm{PVP}^{\circledR}$ (Polivinilpirrolidona), cisteína, ácido ascórbico, ácido cítrico, além dos solidificantes do meio de cultura: agarose, ágar, Phytagel ${ }^{\circledR}$ e ainda, a exclusão dos nutrientes cobre e ferro do meio de cultura. Melhor controle de oxidação foi observado em embriões cultivados em meios de cultura acrescido de $2 \mathrm{~g} \mathrm{~L}^{-1}$ de carvão ativado ou solidificado com phytagel.
\end{abstract}

Palavras-chave: germinação de embriões, oxidação, Strelitzia, floricultura

\author{
ABSTRACT \\ Oxidation control in the in vitro culture of strelitzia (Strelitzia reginae )
}

The propagation of strelitzia (Strelitzia reginae Ait) is obtained through sprout division or seeds. The seeds present slow germination and dormancy. Since the development of this plant is slow, its production and propagation are also delayed besides the reduced number of obtained plants. By using tissue culture techniques it is possible to propagate the species although explant and culture medium oxidation has been observed. The objective of this work was to test chemical compounds added to the culture medium to control the oxidation process. Activated charcoal, $\mathrm{PVP}^{\circledR}$ (polyvinylpyrrolidone), cysteine, ascorbic acid, citric acid were added to the culture medium and different gelling substances such as agarose, agar and Phytage ${ }^{\circledR}$ and the exclusion of iron and cupper from the culture medium were tested. Control of oxidation process was observed cultivating embryos in medium containing $2 \mathrm{~g} \mathrm{~L}^{-1}$ activated charcoal or solidified with phytagel.

Key words: embryo germination, oxidation, Strelitzia, floriculture

\section{INTRODUÇÃO}

A estrelícia (Strelitzia reginae Ait.) é uma planta ornamental de expressivo valor comercial e sua produção desperta especial interesse no mercado externo. A técnica de micropropagação é uma importante alternativa para a propagação dessa espécie, que tem lento desenvolvimento das plantas oriundas de sementes e pequeno número de mudas formadas por divisão de touceiras. No seu processo de cultivo in vitro, no entanto, ocorre oxidação dos explantes e do meio de cultura.

Em algumas plantas, a liberação de exsudatos constitui um dos maiores problemas para o cultivo in vitro (QUERALT et al., 1991). A variação de intensidade de oxidação, no entanto, pode ser inerente às diferentes espécies ou variedades. Em sorgo, por exemplo, diferentes cultivares têm variações de tolerância à oxidação e de coloração dos pigmentos liberados (CAI e BUTLER, 1990). Um dos trabalhos pioneiros de cultivo de estrelícia in vitro foi o ZIV E HALEV (1983), porém, não há nenhum registro de controle de oxidação.

Para prevenir a ocorrência de oxidação, GEORGE (1996b) recomenda minimizar os danos causados ao explante por meio da remoção de compostos fenólicos produzidos e de alterações na composição do meio de cultura. A remoção dos compostos pode ser realizada através da utilização de meios líquidos, de diferentes agentes solidificantes, ou de substâncias de adsorção.

\footnotetext{
(1) Recebido para publicação em 08/06/06 e aceito em 13/08/07.

(2) Projeto financiado pela FAPEMIG.

(3) Departamento de Agricultura, Universidade Federal de Lavras (UFLA), Lavras (MG), 37200-000, Brasil. pdolivei@ufla.br, bolsista CNPq.

(4) Departamento de Biologia, UFLA, bolsista CNPq.
} 
Para o controle da oxidação, diversos produtos podem ser adicionados ao meio de cultura, como a cisteina, carvão ativado, polivinilpirrolidona (PVP), ácido ascórbico, ou ácido cítrico. Muitas dessas substâncias agem adsorvendo os exsudatos liberados pelos explantes, os quais causam a oxidação (JARRET et al., 1985; GEORGE, 1996b). Outras modificações na composição dos meios de cultura também podem ser eficientes para controle da oxidação como variações na concentração dos sais do meio MS, exclusão ou diminuição de ferro e cobre e variações em tipo e níveis de reguladores de crescimento (JARRET et al., 1985).

Objetivou-se neste trabalho avaliar o efeito da adição ao meio de cultura de substâncias antioxidantes e solidificantes para controlar o processo de oxidação ocorrente no cultivo in vitro de embriões de estrelícia.

\section{MATERIALEMÉTODOS}

Frutos maduros (antes da deiscência) de estrelícia foram coletados de plantas cultivadas no Viveiro de Plantas Ornamentais da Universidade Federal de Lavras, Lavras (MG). Os frutos foram levados para o laboratório onde foram abertos e procedeu-se a retirada das sementes. Estas foram limpas, eliminando-se o arilo e desinfestadas em solução de hipoclorito de sódio (produto comercial) a $30 \%$ (cloro ativo: $2 \%$ ) por 15 minutos, sendo posteriormente lavadas em água destilada autoclavada. Os embriões foram extraídos e inoculados em meio de cultura meio MS (MURASHIGE e SKOOG, 1962) solidificado com $7 \mathrm{~g} \mathrm{~L}^{-1} \mathrm{de}$ ágar e acrescido de $30 \mathrm{~g} \mathrm{~L}^{-1}$ de sacarose, com pH ajustado em 5,8, suplementado com agentes anti-oxidantes. $\mathrm{O}$ material foi mantido em sala de crescimento com temperatura de $26 \pm 1^{\circ} \mathrm{C}$ e fotoperíodo de 16 horas, por 30 dias. consistiram de:

Os experimentos com agentes antioxidantes

a. Experimento 1: Carvão ativado nas concentrações 0 (controle); 0,$5 ; 1 ; 2 ; 4 ; 6 ; 8$ e $10 \mathrm{~g} \mathrm{~L}^{-1}$

b. Experimento 2: Ácido cítrico $(0,100,150 \mathrm{e}$ $\left.200 \mathrm{mg} \mathrm{L}^{-1}\right)$ e ácido ascórbico (0, 50, 100 e $\left.150 \mathrm{mg} \mathrm{L}^{-1}\right)$, em todas as combinações possíveis, perfazendo um fatorial $2 \times 2$.

c. Experimento 3: Cisteína nas concentrações: 0 (controle), 4, 8, 12, 16, 20 e $24 \mathrm{mg} \mathrm{L}^{-1}$.

d. Experimento 4: $\mathrm{PVP}^{\circledR}$ (polivinilpirrolidona 40) nas concentrações: 0 (controle), 50, 100, 200, 400, 600, 800 e $1000 \mathrm{mg} \mathrm{L}^{-1}$.

Num quinto experimento testou-se o comportamento dos embriões cultivados em meio líquido e meios com diferentes solidificantes. No primeiro tratamento, os embriões foram colocados em meio MS líquido utilizando ponte de Heller para sustentação dos mesmos. Para a avaliação de solidificação dos meios utilizaram-se como tratamentos: $3,5 \mathrm{mg} \mathrm{L}^{-1}$ ou 7,0 $\mathrm{g} \mathrm{L}^{-1}$ (controle) de ágar; $4 \mathrm{~g} \mathrm{~L}^{-1}$ agarose ou $6 \mathrm{~g} \mathrm{~L}^{-1}$ Phytagel $^{\circledR}$ (produto comercial à base de ágar de algas - marca Sigma).
Testou-se também o efeito da exclusão de ferro e de cobre do meio de cultura, o que constituiu o experimento 6: o meio básico utilizado foi o MS, sendo os tratamentos constituídos de meio MS completo (controle); meio MS sem Fe-EDTA, meio MS sem $\mathrm{CuSO}_{4} 7 \mathrm{H}_{2} \mathrm{O}$, meio MS sem Fe-EDTA e $\mathrm{CuSO}_{4} 7 \mathrm{H}_{2} \mathrm{O}$. Os meios desse experimento foram solidificados com $7 \mathrm{~g} \mathrm{~L}^{-1} \mathrm{de}$ ágar e acrescidos de $30 \mathrm{~g} \mathrm{~L}^{-1}$ de sacarose, tendo o $\mathrm{pH}$ ajustado em 5,8 .

Todos os experimentos foram instalados em delineamento inteiramente casualizado, com 8 repetições, constituídas por um tubo por parcela contendo um embrião. Cada experimento foi analisado individualmente. Após 30 dias, efetuaram-se as avaliações, observando-se a ocorrência de oxidação a partir da coloração do meio de cultura e do embrião. Para avaliação da oxidação foram atribuídas notas em função do gradiente da intensidade de coloração ocorrida no meio de cultura, segundo a escala: 0 - Ausência de oxidação no meio de cultura; $1-1 / 3$ do meio de cultura escurecido (com oxidação); 2 - 2/3 do meio de cultura escurecido e 3 - Meio de cultura totalmente escurecido (O escurecimento do meio ocasionado pelo processo de oxidação já foi registrado por GEORGE, 1996b).

Para a análise estatística, utilizou-se o método não-paramétrico. Para os valores qualitativos realizou-se o teste de Kruskal-Wallis (CAMPOS, 1983). Assim, ajustaram-se modelos de regressão linear simples, com coeficiente de regressão testado conforme o teste de Theil. Os desvios de regressão foram submetidos ao teste de Kruskal-Wallis (5\%), para testar a significância, afirmando ser o modelo ajustado apropriado (HOLLANDER e WOLFE, 1973).

\section{RESULTADOS E DISCUSSÃO}

Observou-se que variações significativas no desenvolvimento das plântulas (tamanho de brotos e de raiz) ocorreram apenas em função dos diferentes solidificantes do meio de cultura utilizados. Diferenças significativas no controle da oxidação foram observadas quando se utilizou PVP ${ }^{\circledR}$, carvão ativado, solidificantes diferentes ou pela exclusão de nutrientes minerais do meio de cultura. O uso de cisteína e ácido ascórbico em combinação com ácido cítrico, nas concentrações testadas, não proporcionou efeito sobre o controle de oxidação.

As concentrações de carvão ativado testadas promoveram variações significativas no controle do processo de oxidação, efeito esse já sugerido por GEORGE (1996a). Observou-se uma tendência de diminuição da ocorrência de oxidação à medida em que foram aumentadas as concentrações de carvão ativado, a partir de $2,0 \mathrm{~g} \mathrm{~L}^{-1}$. O escurecimento ocorreu em maior intensidade em meios com concentrações mais baixas de carvão $\left(0,5\right.$ - 1,0 $\left.\mathrm{g} \mathrm{L}^{-1}\right)$ ou na ausência dessa substância.

$\mathrm{A}$ adição de $\mathrm{PVP}^{\circledR}$ ao meio de cultura, em todas as concentrações testadas, não afetou o desenvolvimento dos embriões, principalmente em concentrações mais elevadas (superiores a $600 \mathrm{mg} \mathrm{L}^{-1}$ ) as quais não causaram toxidez (nenhum sintoma de dano nas 
plantas foi observado). Observa-se na Figura 1 que o PVP ${ }^{\circledR}$ não foi eficiente para o controle da oxidação, apesar de sua maior efetividade já comprovada em outras culturas (FRIDBORG e ERIKSSON, 1965; ANAGNOSTAKIS, 1974; FRIDBORG et al., 1978; TISSERAT, 1979; TAKAYAMA e MISAWA, 1980; BON et al., 1988; GUERRA e HANDRO, 1988) e também em estrelícia (ZIV e HALEVY, 1983). Foi observada ainda uma tendência de ocorrência de oxidação em maior intensidade quando os embriões foram cultivados em concentrações mais elevadas de $\mathrm{PVP}^{\circledR}$ (Figura 1).

A utilização de diferentes solidificantes no meio de cultura teve efeito tanto no desenvolvimento dos explantes quanto no controle de oxidação. Em meio líquido ou solidificado com 3,5 $\mathrm{g} \mathrm{L}^{-1}$ de ágar ou Phytagel ${ }^{\circledR}$, os embriões tiveram menor desenvolvimento da parte aérea em relação aos outros tratamentos (Figura 2). A utilização de ágar $\left(7 \mathrm{~g} \mathrm{~L}^{-1}\right)$, agarose ou Phytagel ${ }^{\circledR}$ promoveu a formação de brotos em tamanhos estatisticamente iguais, mas superiores aos obtidos nos outros tratamentos (Figura 2). No meio solidificado com agarose, os brotos chegaram ao tamanho médio de $3,18 \mathrm{~cm}$ com amplitude variando de 3,0 a $8,5 \mathrm{~cm}$ aos 30 dias. SZABADOS et al. (1991) também observaram que plantas de mandioca e arroz aumentaram significativamente o crescimento quando cultivados em meios solidificados com agarose e gelrite em comparação com o cultivo em meios solidificados com ágar.

O número de raízes formadas no meio líquido foi menor do que nos embriões cultivados em meios sólidos. Porém, raízes de maior comprimento (maior que $1,5 \mathrm{~cm}$ ) foram obtidas em embriões cultivados nos meios solidificados com ágar em relação aos meios de agarose ou Phytagel ${ }^{\circledR}$ (Figura 3). O uso de meio líquido afetou tanto o desenvolvimento de parte área quanto de raízes, sendo esses formados em menor tamanho $(1,7$ e $0,8 \mathrm{~cm}$, respectivamente). O uso de agarose proporcionou a formação de brotos com maior tamanho $(3,1 \mathrm{~cm})$ e raízes com tamanho $(1,1 \mathrm{~cm})$ reduzido em comparação àquelas formadas em meios com ágar.

A oxidação foi significativamente reduzida no meio solidificado com agarose e não ocorreu em meio solidificado com Phytagel ${ }^{\circledR}$ (Figura 4), possivelmente devido ao fato destes serem produtos mais puros em relação ao ágar, não apresentando elementos químicos que favorecem a oxidação conforme já sugerido por FINCH et al. (1992). Oxidação em maior intensidade (acima de 0,8 segundo a escala de avaliação utilizada) foi observada em meios líquidos e nos solidificados com ágar.

Também se observou que a utilização de meios líquidos ou semi-sólidos (3,5 $\mathrm{g} \mathrm{L}^{-1}$ de ágar) não foi satisfatória para o desenvolvimento dos embriões. Em meio líquido, a parte aérea, possivelmente devido à posição de fixação do embrião, tendeu a desenvolver-se internamente à ponte de Heller, produzindo algumas plântulas deformadas. Além disso, esse meio, assim como o meio semi-sólido não foi eficiente para o controle ou a redução do processo de oxidação como era esperado, pois, conforme GEORGE (1996b), os meios líquidos, por permitirem maior difusão dos exsudatos, são favoráveis para reduzir os efeitos prejudiciais da oxidação, pois evitam que as substâncias liberadas permaneçam junto ao explante, causando toxicidez.

A ocorrência de oxidação foi inibida nos meios cujos solidificantes utilizados foram o Phytagel ${ }^{\circledR}$ e a agarose. Estes agentes, conforme GEORGE (1996a), possuem maior pureza, não ocorrendo em suas constituições outros elementos químicos ou compostos fenólicos na sua composição como é o caso do ágar (DEBERGH, 1983).

Observou-se que o desenvolvimento da parte aérea de explantes de estrelícia cultivados em meio solidificado com Phytagel ${ }^{\circledR}$, foi ligeiramente inferior ao dos explantes solidificados em meios com agarose ou com $7 \mathrm{~g}$ $\mathrm{L}^{-1}$ de ágar. As plantas, no entanto, depois de transferidas para meio solidificado com Phytagel ${ }^{\circledR}$ não oxidaram, demonstrando a eficiência desse produto para controle da oxidação.

A exclusão do nutriente cobre do meio de cultura promoveu variações no controle do processo oxidativo. Meios sem esse elemento, conforme se visualiza na Figura 5 , tiveram oxidação em valores significativamente inferiores em relação aos outros meios testados.

A exclusão de ferro, mesmo associado à exclusão de cobre, não provocou alteração no processo e os resultados compararam-se à testemunha - meio MS contendo ambos os nutrientes. A exclusão desses nutrientes não alterou o desenvolvimento dos explantes.

\section{CONCLUSÕES}

Nas condições em que os trabalhos foram realizados conclui-se que:

- Para controle da oxidação no cultivo in vitro de estrelícia, maior eficiência é observada com a adição de $2 \mathrm{~g} \mathrm{~L}^{-1}$ carvão ativado ou com o uso de Phytagel ${ }^{\circledR}$ para solidificação do meio de cultura.

- O uso de agarose, apesar de não controlar a oxidação, reduz a sua ocorrência.

A utilização dos produtos $\mathrm{PVP}^{\circledR}$, cisteína, ácido cítrico, ácido ascórbico, não é eficiente para controlar a oxidação em cultivo in vitro de embriões de estrelícia.

- A exclusão de cobre do meio de cultura proporcionou redução no processo de oxidação e não afetou o desenvolvimento dos explantes.

\section{REFERÊNCIAS}

ANAGNOSTAKIS, S.L. Haploid plants from anthers of tobacco - Enhancement with charcoal. Planta, Berlin, v.115, p.281-283, 1974.

BON, M.C.; GENDRAUD, M.; FRANCLET, A. Roles of phenolic compounds on micropropagation of juvenile and nature clones of Sequoiadendron giganteum: influence of activated charcoal. Scientia Horticulturae, Amsterdam v.34, n.3-4, p. 283-291, 1988.

CAI, T.; BUTLER, L. Plant regeneration form embryogenic callus initiated from immature inflorescences of several 
high-tannin sorghums. Plant Cell and Organ Culture, Dordrecht, v.20. p.101-110. 1990.

CAMPOS, H.de Estatística experimental não-paramétrica, 4. ed. Piracicaba: ESALQ-USP, 1983.349p.

DEBERGH, P.C. Effects of agar brand and concentration on the tissue culture medium. Physiologia Plantarum, Copenhagen, v.59, p.270-276, 1983.

FINCH, R.P.; BASET, A.; SLAMET, I.H.; COCKING, E.G. In vitro shoot culture of wild Oryza and othergrass species. Plant Cell, Tissue and Organ Culture, Dordrecht, v.30, p.31-39, 1992.

FRIDBORG, G.e ERIKSSOM. T. Effects of activated charcoal on growth and morphogenesis in cell cultures. Physiologia Plantarum, Copenhagen, v.34, p.306-308, 1965.

FRIDBORG, G.; PEDERSON, M.; LANDSTROM, L.E.; ERIKSSOM. T. The effect of activated charcoal on tissue cultures: adsorption of metabolites, inhibition of morphogenesis. Physiologia Plantarum, Copenhagen, v.43, p.104-106, 1978.

GEORGE, E.F. Plant propagation by tissue culture, part 1The Technology, $2^{\text {nd }}$. ed. Edington: Exegetics Limited, 1996a, 1574 p.

GEORGE, E.F. Plant propagation by tissue culture, part 2 In Practice, $2^{\text {nd }}$. ed. Edington: Exegetics Limited, 1996b, 1361p.

GUERRA, M.P.; HANDRO, W. Somatic embryogenesis and plant regeneration in embryo cultures of Euterpe edulis Mart (Palmae). Plant Cell Reports, Baltimore, v.7, p.550$552,1988$.

HOLLANDER, M.e WOLFE, D.A. Nonparametric statistical methods. New York: John Wiley e Sons, 1973. $503 \mathrm{p}$.
JARRET, R.L.; RODRIGUEZ, W.; FRENANDEZ, R. Evaluation, tissue culture propagation and dissemination of 'Saba' and 'Pelipita' plantains in Costa Rica. Scientia Horticulturae, Amsterdam, v.25, p.137-147, 1985.

MURASHIGE, T.; SKOOG,F. A revised medium for rapid growth and bioassays with tobacco tissue cultures. Physiologia Plantarum, Copenhagen, v.15, p.473-497, 1962.

QUERALT, M.C.; BERUTO, M.; VANDERSCHAEGHE,A.; DEBERGH, P.C. Ornamentals. In: DEBERGH, P.C.; ZIMMERMAN, R.H., (Eds.) Micropropagation Technology and Application. Dordrecht, Kluwer: Academic Publishers, 1991. p.215-229.

SZABADOS, L.; NÚÑUZ, V.M.; TELLO, L.M.; MAFLA, G.; ROA, J.; ROCA, W.M. Agentes gelatinizadores em el cultivo de tejidos. In: ROCA, W.H.; MROGINSKI, L.A., (Eds.) Cultivo de tejidos em la agricultura - Fundamentos y aplicaciones. Cali: CIAT, 1991.p.79-93

TAKAYAMA, S. e MISAWA, M. Differentiation in Lilium bulb scales in vitro. Effects of activated charcoal, physiological age of bulbs and sucrose concentration on differentiation and scale leaf formation in vitro. Physiologia Plantarum, Copenhagen, n.48, p.121-125, 1980.

TISSERAT, B. Propagation of date palm (Phoenix dactylifera L.) in vitro. Journal of Experimental Botany, Lancaster, v.30, n.19, p.1275-1283, 1979.

ZIV, M.; HALEVY, A.H. Control of oxidative browning and in vitro propagation of Strelitzia reginae. HortScience, Alexandria, v.18, n.4, p.434-436, 1983.

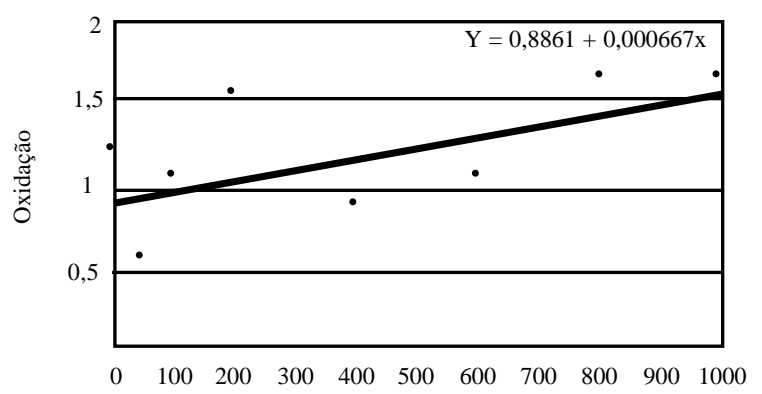

Figura 1. Efeito de PVP e ocorrência de oxidação no cultivo in vitro de embriões de estrelícia. (Critério de notas para ocorrência de oxidação: 0 -Ausência de oxidação no meio de cultura; 1 - 1/3 do meio de cultura escurecido; 2 -2/3 do meio de cultura escurecido e 3 - Meio de cultura totalmente escurecido).

Figure 1. Effect of PVP and occurrence of oxidation on the in vitro culture of strelitzia embryos (Grades criteria for the occurrence of oxidation: 0 - culture medium with absence of oxidation; 1 - culture medium with 1/3 darkness; 2 - culture medium with 2/3 darkness and 3 - culture medium totally Aarark 7,0 Agar 3,5 Líquido Agarose Phytagel 


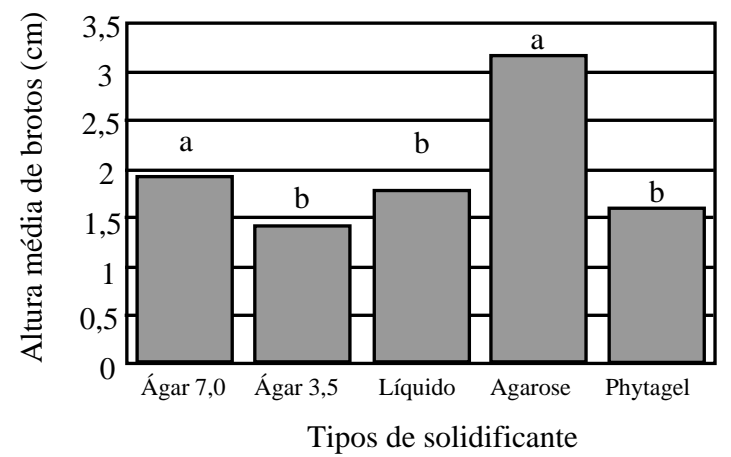

Figura 2. Altura $(\mathrm{cm})$ média de brotos formados em embriões de estrelícia cultivados em meios de cultura solidificados com ágar, agarose, phytagel, ou em meio líquido, após 30 dias de cultivo. Médias seguidas de mesma letra não diferem entre si pelo teste de Kruskal-Wallis (ao nível de 5\%).

Figure 2. Average height $(\mathrm{cm})$ of shoots formed in strelitzia embryos cultivated in culture medium solidified with agar, agarose, phytagel or cultivated in liquid medium during 30 days of culture. Means followed by the same letter showed no differences using the Kruskal-Wallis test (at $5 \%$ level).

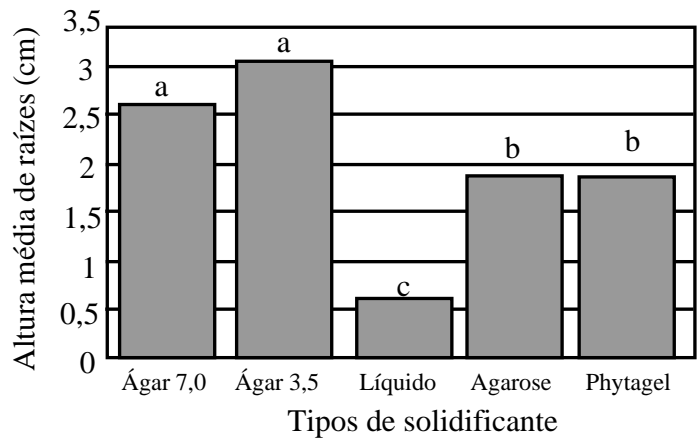

Figura 3. Comprimento médio $(\mathrm{cm})$ das raízes formadas em embriões de estrelícia cultivados em meios de cultura com ágar, agarose, phytagel, ou em meio líquido, após 30 dias de cultivo. Médias seguidas de mesma letra não diferem entre si pelo teste de KruskalWallis ao nível de 5\%.

Figure 3. Average length $(\mathrm{cm})$ of roots formed in strelitzia embryos cultivated in culture medium solidified with agar, agarose, phytagel or cultivated in liquid medium during 30 days of culture. Means followed by the same letter showed no differences using the Kruskal-Wallis test (at 5\% level).

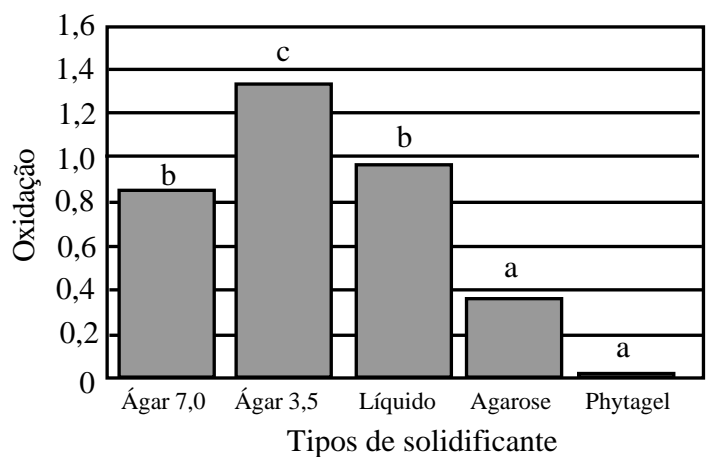

Figura 4. Oxidação ocorrida em meios de cultura solidificados com ágar, agarose, phytagel, ou em meio líquido, após 30 dias, em cultivo de embriões de estrelícia. Médias seguidas de mesma letra não diferem entre si pelo teste de Kruskal-Wallis ao nível de 5\%. (Critério de notas para ocorrência de oxidação: 0 - Ausência de oxidação no meio de cultura; 1 - 1/3 do meio de cultura; 2 -2/3 do meio de cultura e 3 - Meio de cultura totalmente escurecido).

Figure 4. Oxidation in culture medium solidified with agar, agarose, phytagel or in liquid medium, after 30 days, of strelitzia embryo culture. Means followed by the same letter showed no differences using the Kruskal-Wallis test at $5 \%$ level. (Grades criteria for the occurrence of oxidation: 0 - culture medium with absence of oxidation; 1 - culture medium with 1/3 darkness; 2 - culture medium with 2/3 darkness and 3 - culture medium totally dark). 


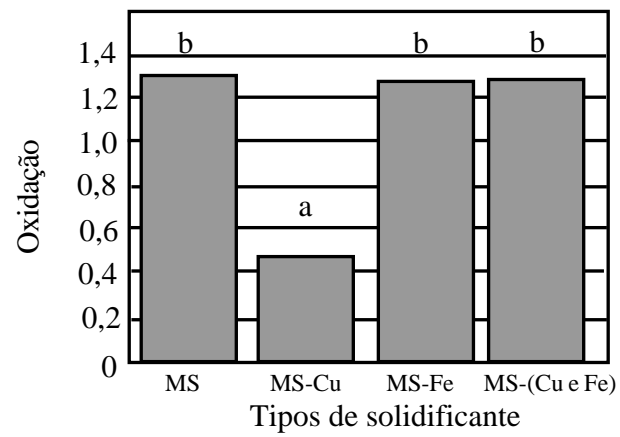

Figura 5. Efeito da exclusão dos nutrientes ferro $(\mathrm{Fe})$ e cobre $(\mathrm{Cu})$ do meio de cultura MS sobre o controle de oxidação em cultivo in vitro de embriões de estrelícia, após 30 dias. Médias seguidas de mesma letra não diferem entre si pelo teste de Kruskal-Wallis ao nível de 5\%.(Critério de notas para ocorrência de oxidação: 0 - Ausência de oxidação no meio de cultura; 1 - 1/3 do meio de cultura escurecido; $2-2 / 3$ do meio de cultura escurecido e 3 - Meio de cultura totalmente escurecido).

Figure 5. Effect of the exclusion of iron ( $\mathrm{Fe})$ and cupper $(\mathrm{Cu})$ nutrients from the MS culture medium on the control of oxidation after 30 days of in vitro culture of strelitzia embryos. Means followed by the same letter showed no differences using the Kruskal-Wallis test at $5 \%$ level. (Grades criteria for the occurrence of oxidation: 0 - culture medium with absence of oxidation; 1 - culture medium with 1/3 darkness; 2 - culture medium with 2/3 darkness and 3 - culture medium totally dark) 